\title{
IDENTIFIKASI GAYA KEPEMIMPINAN KEPALA SEKOLAH
}

\author{
Nurzaima \\ Universitas Muhammadiyah Kendari \\ Nur_zaima@yahoo.com
}

\begin{abstract}
ABSTRAK
Rumusan masalah dalam penelitian ini adalah bagaimana gaya kepemimpinan kepala sekolah yang demokratis. Tujuan penelitian ini adalah untuk mendeskripsikan gaya kepemimpinan kepala MTs Al-Ikhwan Labungka. Manfaat penelitian ini ada dua yaitu; manfaat teoritis; memberikan informasi baru dalam pendidikan khususnya pengelolaan manajemen oleh para kepala sekolah dalam peningkatan mutu pendidikan yang tercermindalam kualitas sekolah. dan manfaat praktis; membantu kepala sekolah mengungkapkan taraf posisi keberhasilan Mts Al-Ikhwan Labungka. Jenis penelitian ini adalah kualitatif deskriptif. Teknik pengumpulan data dilakukan dengan observasi, wawancara, dan dokumentasi. Adapun yag diwawancara dalam penelitian ini adalah 4 orang guru, kepala sekolah, dan wakil kepala sekolah bagian kurikulum. Teknik analisis data dilakukan melalui empat tahapan yang meliputi: pengumpulan data, reduksi data, penyajian data, dan penarikan kesimpulan/verifikasi. Keabsahan data. Hasil penelitian diperoleh bahwa gaya kepemimpinan kepala sekolah di MTs Al-Ikhwan diimplementasikan sesuai kriteria pemimpin yang demokratis yaitu melibatkan bawahannya dalam musyawarah untuk peningkatan mutu pendidikan dan menjalin komunikasi yang lebih baik bagi hubungan formal dan informal. Kepala sekolah juga selalu memperlakukan dan memuaskan kebutuhan bawahannya dengan adil. Dengan gaya kepemimpinan seperti ini maka sekolah tersebut dapat memiliki keampuan yang memadai.
\end{abstract}

Kata Kunci: kepemimpinan, gaya kepemimpinan.

\section{ABSTRACT}

The formulation of the problem in this research is how the leadership style of the principal is democratic. The purpose of this study was to describe the leadership style of MTs Al-Ikhwan Labungka. The benefits of this research are two namely; theoretical benefits; provide new information in education, especially management by principals in improving the quality of education that is reflected in the quality of schools. and practical benefits; helped the principal reveal the level of success of Mts Al-Ikhwan Labungka. This type of research is qualitative descriptive. Technique of data collection is done by observation, interview, and documentation. The interviewees in this study were 4 teachers, headmasters, and deputy head of the school curriculum section. Data analysis technique is done through four stages which include: data collection, data reduction, data presentation, and conclusion/verification. The result of the research shows that the principal leadership style in MTs Al-Ikhwan is implemented according to the criteria of democratic leader which involves subordinates in deliberation to improve the quality of education and establish better communication for formal and informal relationship. The principal also always treats and satisfies the needs of his subordinates fairly. With this style of leadership then the school can have adequate ability.

Keywords: leadership, leadership style.

\section{PENDAHULUAN}

$\begin{array}{llr}\text { Kehidupan } & \text { organisasi selalu } \\ \text { dihubungkan } & \text { dengan siapa } \\ \text { pemimpinnya } & \text { dan bagaimana }\end{array}$

memimpinnya (Samino, 2012: 15). Demikian juga sekolah atau perguruan tinggi itu maju atau tidak selalu dihubungkan dengan kepala 
sekolah atau rektornya ini, kepemimpinan menjadi sangat (pimpinannya). Anggapan tersebut memang tidak dapat disalahkan secara mutlak, tetapi bisa dipertimbangkan sebagai suatu hal yang benar. Oleh karena itu, semua orang menyadari bahwa seorang pemimpin memiliki posisi yang sangat strategis dan berperan dalam memajukan atau mengembangkan sekolah.

Era desentralisasi dan otonomi daerah telah membawa implikasi besar terhadap penyelenggaraan dan pengelolaan pendidikan. Kewenangan penyelenggaraan pendidikan dasar dan menengah (kecuali madrasah) berdasarkan PP No. 38 tahun 2007 didelegasikan kewenangan penyelenggaraannya kepada pemerintah daerah kabupaten/kota. Hanya Sekolah Luar Biasa (SLB) dan sekolah pada jenjang pendidikan dasar dan menengah yang berada pada perbatasan kabupaten/kota berada dalam kewenangan pemerintah provinsi. Sementara itu, pemerintah pusat berperan dalam menetapkan standar penyelenggaraan pendidikan, yang meliputi: standar kompetensi lulusan (SKL), standar isi, standar penilaian, standar pendidik dan tenaga kependidikan, standar pembiayaan, standar sarana dan prasarana, standar pengelolaan, serta standar proses di jenjang pendidikan dasar dan menengah.

Berdasarkan sudut pandang penyelenggaraan pendidikan dewasa penting dan cenderung menyisakan permasalahan, terutama bila dipandang dari 2 (dua) hal, pertama adanya kenyataan bahwa penggantian pemimpin (suksesi kepemimipinan) seringkali mengubah kinerja suatu unit, instansi atau organisasi; kedua, hasil penelitian menunjukkan bahwa kepemimpinan menjadi salah satu faktor internal yang mempengaruhi keberhasilan organisasi, namun pada kenyataannya dipandang tidak penting. Sehingga yang terjadi adalah organisasi memiliki pemimpin/kepala namun gagal dalam menghadirkan leadership (Yukl, 1989). Hasil penelitian tersebut membuktikan adanya jargon "ganti pimpinan, ganti kebijakan", bahkan sampai hal-hal teknis seperti ganti tata ruang kantor, ganti kursi, atau ganti warna dinding, bukan sistem yang bekerja.

Sebagai sekolah yang tergolong baru, Madrasah Tsanawiyah Swasta (MTs) Al-Ikhwan tidak luput dari peran kepala sekolah dalam memenejemen sekolah agar lebih maju dan berkembang. MTs Swasta Al-Ikhhwan adalah sekolah sederajat dengan Sekolah Menengah Pertama (SMP) yang terletak di desa Labungka kabupaten Muna-Sulawesi Tenggara. Sekolah ini merupakan sekolah tepian, karena desa Labungka sendiri secara geografis berada dipesisir laut Muna. Meskipun demikian, sebagain besar masyarakatnya bermata pencaharian sebagai petani, nelayan, 
dan yang lainnya adalah pegawai pemerintah. Kualitas kepemimpinan kepala sekolah sangat signifikan bagi keberhasilan sekolah, karena kepala sekolah adalah seorang tenaga fungsional yang diberi tugas memimpin suatu lembaga sekolah yang menyelenggarakan proses belajar mengajar (Wagiman, 2005). Peranan kepala sekolah dalam rangka mutu pendidikan sangat penting karena dapat mempengaruhi berhasil dan tidaknya mutu pendidikan itu sendiri.

Berdasarkan uraian-uraian pada latar belakang di atas, maka penulis merumuskan masalah penelitian yakni: Bagaimana gaya kepemimpinan kepala sekolah yang demokratis di MTs Swasta Al-Ikhwan Labunga kabupaten Muna?

\section{Konsep Kepemimpinan}

Kepemimpinan berasal dari kata pemimpin yang artinya orang yang melakukan pengaruh terhadap bawahan. Jadi tanpa adanya seorang pemimpin maka suatu kepemimpinan tidak akan terjadi. Dalam mendefinisikan arti kepemimpinan terdapat beberapa pendapat berbeda yang dikeluarkan oleh masing-masing ahli. Menurut Wirawan (dalam Sagala 2000: 144) memberi pengertian kepemimpinan sebagai proses pemimpin menciptakan visi, mempengaruhi sikap, perilaku, pendapat, nilai-nilai, norma dan sebagainya dari pengikut untuk merealisasi visi.

Kemudian George Terry (dalam Sagala 2000: 144) mendefinisikan kepemimpinan adalah "hubungan antara seorang pemimpin dalam mempengaruhi orang lain untuk bekerja sama secara sadar dalam hubungan tugas untuk mencapai keinginan pemimpin". Sementara itu rumusan kepemimpinan oleh Akademi Militer West Point (dalam Sagala 2000: 145) kepemimpinan adalah proses mempengaruhi perilaku seseorang dalam mencapai tujuan organisasi. Stephen Robbins (dalam Wahab 2006: 82) juga menerangkan bahwa kepemimpinan adalah kemampuan dalam mempengaruhi orang lain untuk mencapai tujuan yang telah ditetapkan.

Pendapat ini memandang bahwa semua anggota kelompok/organisasi merupakan satu kesatuan yang utuh dimana dapat melakukan pekerjaan guna pencapaian tujuan organisasi. Kepemimpinan pula merupakan suatu proses penggunaan kekuasaan atau wewenang yang dimiliki dalam menggerakkan sistem sosial guna mencapai tujuan sosial. Terdapat beberapa gambaran pula mengenai pengertian kepemimpinan, diantaranya: Menurut Stogdill (dalam Wahab 2006: 132), kepemimpinan adalah proses mempengaruhi kegiatan-kegiatan kelompok yang diorganisir menuju kepada 
penentuan dan pencapaian tujuan. Menurut Siagian (2006: 132), "Kepemimpinan merupakan motor atau daya penggerak daripada semua sumber-sumber, plat yang tersedia bagi suatu organisasi". Menurut Dubin (Wahab 2006: 133), "Kepemimpinan dalam organisasi berarti penggunaan kekuasaan dan pembuatan keputusan-keputusan". Menurut Fiedler (2006: 133), "Kepemimpinan adalah individu di dalam kelompok yang memberikan tugas pengarahan pengorganisasian yang relevan dengan kegiatankegiatan kelompok".

Kesimpulan dari pengertian kepemimpinan adalah suatu kualitas kegiatan-kegiatan dan integritas di dalam situasi pendidikan. Sedangkan kepemimpinan pendidikan merupakan kemampuan untuk mengerakkan pelaksana pendidikan, sehingga tujuan pendidikan yang telah ditetapkan dapat tercapai secara efektif dan efisien. Berdasarkan beberapa pendapat diatas dapat disimpulkan bahwa kepemimpinan merupakan suatu usaha yang dilakukan oleh seorang pemimpin untuk mempengaruhi orang lain (bawahan) agar mau bekerja sama ataupun taat terhadap segala perintah yang dikeluarkan guna mencapai tujuan yang telah ditetapkan. Kegiatan-kegiatan dalam suatu kepemimpinan mencakup pemberian dorongan, motivasi, dan pengarahan terhadap bawahan untuk menyelesaikan pekerjaan dengan sepenuh hati. Sehingga komponenkomponen yang ada dalam suatu kepemimpinan, yakni: 1) perilaku (aktivitas) pemimpin; 2) hubungan kekuasan dengan anggota; 3) interaksi; 4) inisiatif dalam mempengaruhi orang lain.

Pemimpin menurut Anoraga (2002) adalah seorang yang mempunyai wewenang untuk memerintah orang lain, yang di dalam pekerjaannya untuk mencapai tujuan organisasi memerlukan bantuan orang lain. Menurut Kartono (2008) pemimpin adalah pribadi yang memiliki kecakapan khusus, dengan atau tanpa pengangkatan resmi dapat mempengaruhi kelompok yang dipimpinnya, untuk melakukan usaha bersama mengarah pada pencapaian sasaran-sasaran tertentu.

\section{Fungsi dan Ciri-Ciri Gaya Kepemimpinan}

Fungsi kepemimpinan menurut Kartono (2008) adalah memandu, menuntun, membimbing, membangun, memberi motivasi kerja, memberikan pengawasan yang efisien dan membawa pengikutnya kepada sasaran yang dituju. Dalam mewujudkan

fungsi-fungsi kepemimpinan secara integral, sebagaimana telah dikemukakan di atas, akan berlangsung aktivitas kepemimpinan. Apabila aktivitas tersebut dipilah-pilah maka akan terlihat gaya kepemimpinannya dengan pola masing-masing.. 
Menurut Newman (dalam Thoha, 2003: 262) kepemimpinan adalah kegiatan untuk mempengaruhi perilaku orang lain atau seni mempengaruhi perilaku manusia baik perorangan maupun kelompok. Dan satu hal yang perlu diingat bahwa kepemimpinan tidak harus dibatasi oleh aturan-aturan atau tata karma birokrasi. Kepemimpinan bisa terjadi dimana saja, asalkan seseorang menunjukkan kemampuannya mempengaruhi perilaku orang lain ke arah tercapainya suatu tujuan tertentu. Bahasan mengenai pemimpin dan kepemimpinan pada umumnya menjelaskan bagaimana untuk menjadi pemimpin yang baik, gaya dan sifat yang sesuai dengan kepemimpinan serta syarat-syarat apa yang perlu dimiliki oleh seorang pemimpin yang baik. Meskipun demikian masih tetap sulit untuk menerapkan seluruhnya, sehingga dalam prakteknya hanya beberapa pemimpin saja yang dapat melaksanakan kepemimpinannya dengan baik dan dapat membawa para pengikutnya kepada keadaan yang diinginkan.

Kepemimpinan dapat dikategorikan sebagai ilmu sosial terapan (applied social sciences). Hal ini didasarkan kepada pemikiran bahwa kepemimpinan dengan prinsip-prinsipnya mempunyai manfaat langsung dan tidak langsung terhadap upaya mewujudkan kesejahteraan umat manusia.
Kepemimpinan seperti halnya ilmuilmu yang lain, mempunyai berbagai fungsi antara lain, menyajikan berbagai hal yang berkaitan dengan permasalahan dalam kepemimpinan dan memberikan pengaruh dalam menggunakan berbagai pendekatan dalam hubungannya dengan pemecahan aneka macam persoalan yang mungkin timbul dalam ekologi kepemimpinan.

Gaya kepemimpinan, mengandung pengertian sebagai suatu perwujudan tingkah laku dari seorang pemimpin, yang menyangkut kemampuannya dalam memimpin. Perwujudan tersebut biasanya membentuk suatu pola atau bentuk tertentu. Pengertian gaya kepemimpinan yang demikian ini sesuai dengan pendapat yang disampaikan oleh Davis dan Newstrom (2005: 49). Keduanya menyatakan bahwa pola tindakan pemimpin secara keseluruhan seperti yang dipersepsikan atau diacu oleh bawahan tersebut dikenal sebagai gaya kepemimpinan.

Mengacu pada pendapat para ahli seperti di atas, maka gaya kepemimpinan dapat diartikan sebagai pola atau bentuk dari suatu tindakan yang dilakukan oleh seseorang dalam mempengaruhi perilaku orang lain dalam rangka mencapai suatu tujuan tertentu yang dipersepsikan oleh orang-orang yang dipengaruhinya. Berdasarkan simpulan tersebut, maka gaya kepemimpinan kepala sekolah dapat 
diartikan sebagai persepsi para guru dan seluruh karyawan suatu sekolah terhadap pola atau bentuk dari tata cara seorang kepala sekolah dalam mempengaruhi para bawahannya untuk mencapai tujuan dari sekolah tersebut.

\section{Teori-Teori Tentang Kepemimpinan}

Secara singkat dapat

dikemukakan bahwa teori tentang kepemimpinan dapat dikelompokkan dalam tiga pendekatan, yaitu: pendekatan sifat, pendekatan perilaku, dan pendekatan situasional (Lunenburg \& Ornstein, 1991: 129153, Handoko, 2001: 295; GomesMejia \& Balkin, 2002: 290-312 2002, Wirjana \& Supardo, 2005: 13).

a. Pendekatan Sifat

Teori pendekatan sifat ini memusatkan perhatian pada diri para pemimpin itu sendiri, oleh karena itu teori ini lebih dikenal sebagai teori pembawaan. Dalam teori ini disebutkan bahwa pemimpin memiliki ciri-ciri atau sifat-sifat tertentu yang menyebabkan ia dapat memimpin para pengikutnya.

b. Pendekatan Perilaku

Pendekatan perilaku mencoba mengoreksi pendekatan sifat. Menurut pendekatan perilaku, pendekatan sifat tidak dapat menjelaskan apa yang menyebabkan kepemimpinan itu efektif. Oleh karenanya, pendekatan perilaku tidak lagi berdasarkan pada sifat seorang pemimpin melainkan mencoba menentukan apa yang dilakukan oleh pemimpin efektif, seperti bagaimana mereka mendelegasikan tugas, bagaimana mereka berkomunikasi dan memotivasi bawahan, bagaimana mereka menjalankan tugas-tugas dan sebagainya.

Seorang pemimpin dengan gaya kepemimpinan berorientasi tugas akan berusaha mendorong bawahannya melaksanakan tugas yang sesuai dengan keinginannya. Jadi pelaksanaan pekerjaan lebih penting dari pengembangan dan pertumbuhan karyawan. Sedangkan pemimpin yang berorientasi pada karyawan lebih melihat karyawan secara manusiawi, sehingga mereka akan selalu memberikan motivasi, melibatkan karyawan dalam pengambilan keputusan, menciptakan persahabatan dan saling menghormati.

c. Pendekatan Situasional Banyak penelitian mengindikasikan bahwa tidak ada satupun gaya kepemimpinan yang tepat bagi setiap pemimpin untuk berbagai kondisi. Oleh karenanya, lahirlah pendekatan situasional. Pendekatan ini didasarkan pada keyakinan bahwa para pemimpin dalam menjalankan kepemimpinannya, terutama pada aktifitas pengambilan keputusan, dipengaruhi oleh situasi dan kondisi tertentu. Teori lain tentang 
kepemimpinan situasional adalah Teori Hersey-Blanchard. Menurut Siagian (2003:139) pada intinya teori ini menekankan bahwa efektivitas kepemimpinan seseorang tergantung pada dua hal, yaitu pemilihan gaya kepemimpinan yang tepat untuk menghadapi situasi tertentu dan tingkat kematangan (kedewasaan) yang dipimpin. Dua dimensi kepemimpinan yang digunakan dalam teori ini ialah perilaku seorang pimpinan yang berkaitan dengan tugas kepemimpinannya dan hubungan atas-bawahan atau patron-client. Tergantung pada orientasi tugas kepemimpinan dan sifat hubungan atasan dan bawahan yang digunakan, gaya kepemimpinan yang timbul dapat mengambil empat bentuk, yaitu: memberitahukan, menjual, mengajak bawahan berperan serta dan pendelegasian.

\section{Ciri-Ciri Gaya Kepemimpinan}

Menurut Bass dan Yukl (2000) menyatakan bahwa meningkatkan kebutuhan-kebutuhan bawahan ke tingkat yang lebih tinggi dan mendorong mereka untuk melebihi minat-minatnya sendiri bagi kepentingan organisasi. Perilaku pemimpin yang demikian yang disebut transformasional atau kharismatik.

a. Kepemimpinan Transaksional lebih terfokus pada kompromi, intrik, dan pengendalian. Pemimpin transaksional juga dianggap lebih konservatif. Lebih lanjut, Bass et.al menyatakan bahwa semua teori kepemimpinan transaksional seperti kepemimpinan otoratik dan demokratik fokus pada cara pengambilan keputusan apakah direktif atau partisipatif, apakah yang dipimpin fokus pada tugas atau pada hubungan interpersonal maupun perilaku yang dilakukan apakah inisiasi atau konsiderasi, (Bass, 2000).

b. Kepemimpinan Transformasional mulai muncul karena adanya perubahan yang cepat di dunia internasional yang meningkatkan kompetisi antar organisasi, sehingga pola perilaku transaksional dari pemimpin dirasa tidak lagi memadai. Berdasarkan pendapat Bass (2000), kepemimpinan transformasional merupakan pengaruh pimpinan terhadap pengikut atau bawahan. Pengikut merasakan adanya kepercayaan, kebanggaan, loyalitas, dan rasa hormat kepada atasan atau pimpinan, dan mereka termotivasi untuk melakukan sesuatu yang melebihi apa yang diharapkan.

Faktor-Faktor yang Menyebabkan Kepemimpinan Pada Seseorang

Menurut Handoko (2001), ada beberapa pendekatan kepemimpinan yang diklasifikasikan sebagai pendekatan-pendekatan kesifatan, perilaku, dan situasional. Pendekatan 
pertama memandang kepemimpinan sebagai suatu kombinasi sifat-sifat yang tampak. Pendekatan kedua bermaksud mengidentifikasikan perilaku-perilaku (behaviours) pribadi yang berhubungan dengan kepemimpinan yang efektif. Kedua pendekatan ini mempunyai anggapan bahwa seorang individu yang memiliki sifat-sifat tertentu atau memperagakan perilaku-perilaku tertentu akan muncul sebagai pemimpin dalam situasi kelompok apapun dimana ia berada. Pendekatan ketiga yaitu pandangan situasional tentang kepemimpinan.

\section{Indikator Kepemimpinan Kepala Sekolah}

Diafirmasi oleh Greenfield
(2007) bahwa indikator kepala
sekolah yang efektif secara umum
dapat diamati dari tiga hal pokok
sebagai berikut:

a. Komitmen terhadap visi sekolah dalam menjalankan tugas dan fungsiya.

b. Menjadikan visi sekolah sebagai pedoman dalam mengelola dan memimpin sekolah, dan

c. Senantiasa memfokuskan kegiatannya terhadap pembelajaran dan kinerja guru di kelas.

\footnotetext{
Ungkapan tersebut sejalan dengan temuan Heck, dkk. (2001) bahwa prestasi akademik dapat diprestasi berdasarkan pengetahuan terhadap perilaku kepemimpinan
}

kepala sekolah. Hal tersebut dapat dipahami karena proses kepemimpinan kepala sekolah mempunyai pengaruh terhadap kinerja sekolah secara keseluruhan.

\section{METODE PENELITIAN}

Jenis penelitian ini adalah penelitian kualitatif. Menurut Nana Syaodih (2007: 60) qualitative research adalah suatu penelitian yang ditujukan untuk mendeskripsikan dan menganalisis fenomena peristiwa, aktivitas sosial, sikap, kepercayaan, persepsi, pemikiran orang secara individual atau berkelompok. Sumber data dalam penelitian ini meliputi informan, dokumen dan arsip. Dalam hal ini yang menjadi informan dalam penelitian ini adalah kepala sekolah, wakil kepala sekolah bagian kurikulum, 6 orang guru, dan 2 orang siswa di MTs Il-Ikhwan Labungka. Teknik pengumpulan data yang digunakan adalah teknik interaktif yang meliputi wawancara mendalam; bermaksud memperoleh gambaran mengenai gaya kepemimpinan kepala sekolah untuk memenuhi visi sekolah. Observasi; bermaksud untuk memperoleh kegiatan komponen sekolah dalam hal implementasi gaya kepemimpinan kepala sekolah. arsip catatan atau dokumen; data yang diperoleh dari teknik-teknik lainnya, dan pengamatan, (Komariah, 2011: 103).

Teknik analisis data menggunakan model analisis data dalam penelitian ini menggunakan 
metode analisis data tertata dalam situs untuk deskripsi. Sebuah matriks deskriptif yang tertata menurut situs berisi data deskriptif tingkat pertama dari semua situs, tetapi situs ditata menurut variabel utama yang sedang diuji. Miles dan Huberman, (Sugiyono, 2011: 334-335). Keabsahan data menggunakan triangulasi sumber.

\section{HASIL DAN PEMBAHASAN}

1. Tugas Kepala Sekolah Dalam Membuat Keputusan

Pengambilan keputusan merupakan salah satu hal terpenting dalam manajemen. Pengambilan keputusan tidak dapat dipisahkan dari kepemimpinan. Untuk mengetahui mekanisme pembuatan keputusan yang dilakukan oleh kepala sekolah sebagai manajer. Berdasarkan hasil interview yang dilakukan kepada beberapa responden di atas disimpulkan bahwa mekanisme pembuatan keputusan dan penetapan kebijakan berciri "bottom up" yang berarti memperhatikan masukan atau saran dari bawah. Pembuatan keputusan pembagian tugas guru dan staf terlebih dahulu didiskusikan dengan berbagai pihak terkait agar terus terpelihara tanggungjawab dan rasa memliki. Hasil observasi peneliti terkait fungsi kepala sekolah sebagai pengambil keputusan bahwa keputusan yang diambil kepala sekolah melalui jalan musyawarah bersama dewan guru dan lain-lainnya. Namun, kepala sekolah juga mengambil keputusan sendiri tanpa melibatkan guru dengan alasan darurat asalkan tidak berakibat fatal bagi sekolah. Prosedur partisipasi dalam pembuatan keputusan membantu penyatuan tujuan individu dengan tujuan organisasi.

Pembuatan keputusan oleh kepala sekolah merupakan salah fungsi dari tugas kepala sekolah sebagai seorang leader/pemimpin. Dari hasil pengamatan peneliti juga terlihat dari beberapa hal yang sangat sederhana. Contohnya ketika ada seorang siswa yang melakukan pelanggaran ringan seperti tidak mengenakan seragamnya dengan rapi, kepala sekolah bertindak sangat bijaksana. Selain memberikan nasehat kepada siswa yang terkait untuk mentaati peraturan sekolah sehingga tidak terulang dimasa yang akan datang, kepala sekolah juga membebani mereka melakukan kerja sosial di lingkungan sosial; membersihkan lapangan atau toilet. Tugas tersebut dijalani siswa atas dasar kesadaran, karena putusan yang dijatuhkan kepadanya diperoleh melalui kesepakatan antara dua belah pihak. Hal ini didukung oleh gaya kepemimpinan demokratis memberikan tanggung jawab dan 
wewenang kepada semua pihak, sehingga mereka ikut terlibat aktif dalam organisasi, (Wahjosumidjo, 2001: 40). Kepemimpinan ini memandang bawahan sebagai bagian dari keseluruhan organisasinya, sehingga bawahan mendapat tempat sesuai dengan harkat dan martabatnya sebagai manusia. Pemimpin mempunyai tanggung jawab dan tugas untuk mengarahkan, mengontrol dan mengevaluasi serta mengkoordinasi. Kepemimpinan demokratis senantiasa melibatkan partisipasi bawahan atau pengikutnya untuk mengambil keputusan.

\section{Tugas Kepala Sekolah dalam Menetapkan Kebijakan}

Berdasarkan hasil observasi tersebut diketahui bahwa kebijakan-kebijakan dari kepala sekolah ditempuh dengan mengadakan rapat bersama dewan guru dan komite sekolah sehingga bisa diperoleh banyak masukan. Dari masukan-masukan yang ada lalu dipilih alternatif yang terbaik untuk ditetapkan sebagai suatu kebijakan atas pertimbangan semua situasi dan kondisi sekolah. Adapun kebijakan yang dimaksud adalah ketentuan dari pimpinan yang berbeda dengan aturan yang ada, yang dikenakan kepada seseorang karena adanya alasan yang dapat di terima untuk tidak memberlakukan aturan yang berlaku. kebijakan juga dimaknai stakeholders sebagai pernyataan tentang sasaran dan satu atau lebih pedoman yang luas untuk mencapai sasaran tersebut sehingga dapat dicapai yang dilaksanakan bersama dan memberikan kerangka kerja bagi pelaksanaan program. Kebijakankebijakan tersebut dilahirkan melalui tiga tahap kebijakan yaitu: formulasi, implementasi dan evaluasi.

Kepala sekolah sebagai petugas yang profesional dituntut untuk memformulasikan, mengimplementasikan dan mengevaluasi dari kebijakan pendidikan tersebut. Adapun tahap-tahap dalam proses pembuatan kebijakan pendidikan: 1) Penyusunan agenda, yakni disini menempatkan masalah pada agenda sekolah; 2) Formulasi kebijakan, yakni merumuskan alternatif kebijakan untuk mengatasi masalah; 3) Adopsi kebijakan, yakni kebijakan alternatif tersebut diadopsi/diambil untuk solusi dalam menyelesaikan masalah tersebut; 4) Implementasi kebijakan, yakni kebijakan yang telah diambil dilaksanakan dalam sekolah; 5) Penilaian kebijakan, yakni tahap ini tahap penilaian dalam pembuatan kebijakan dan pencapaian tujuan dalam kebijakan sekolah. Dalam hal 


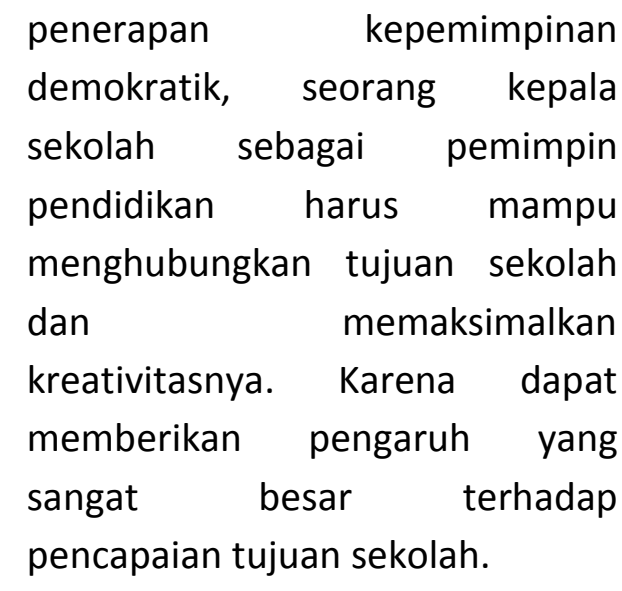

3. Tugas Kepala Sekolah dalam Membangun Pola Komunikasi

Berdasarkan hasil observasi, bahwa komunikasi kepala sekolah ke guru dan siswa berperan sama yaitu pemberi aksi dan penerima aksi. Disini, sudah terlihat hubungan dua arah. Pola komunikasi kepala sekolah berjalan dua arah (komunikatif), sehingga setiap masalah apapun dapat dipecahkan bersama Bentuk komunikasi juga dijalankan secara dialogis dan multi arah, dalam arti mengacu kepada potensi yang dimiliki oleh komite sekolah atau guru dan staf. Hasil observasi peneliti diketahui pola komunikasi yang dilakukan oleh kepala sekolah guna menjaga hubungannya dengan para bawahannya yaitu: 1) kepala sekolah selalu memberikan ruang aspirasi kepada bawahannya; 2) kepala sekolah memberikan kebebasan kepada bawahannya untuk menunjukkan kemampuannnya. Contohnya kepada guru dengan kebebasannya dalam memperlihatkan kemampuannya mendidikan peserta didik dengan berbagai kreatifitasnya; 3) diluar jam kerja, kepala sekolah sering berkumpul santai dengan para guru untuk menjaga hubungan kekelaurgaan. Artinya, secara personal keduanya selalu menjaga hubungan kekeluargaan dengan baik; 4) kepala sekolah berusaha untuk selalu transparan dalam mengelola sekolah, dan juga dalam urusan informasi dan kesempatan bagi guru; serta 5) kepala sekolah selalu mengajal berdialog dan musyawarah jika didapati permasalahan yang melibatkan sekolah dan guru.

Berdasarkan beberapa uraian di atas, dapat disimpulkan bahwa kepala MTS AL-ikhwan Labungka memang tidak membatasi diri dalam waktu dan tempat untuk saling berinteraksi dengan bawahannya. selain pada jam kerja (di sekolah), kepala sekolah juga selalu menjaga hubungan komunikasinya dengan guru di luar jam kerja. Dalam arti luar, pola komunikasi yang dilakukan kepala sekolah adalah bentuk komunikasi organisasi. Yakni komunikasi yang terjadi melalui institusi. Di sekolah telah diatur struktur organisasnya, seperti kepala sekolah, wakil kepala sekolah, guru dan lainlainnya. Semuanya memiliki fungsi dan perannya masing-masing. Akan tetapi di luar institusi pun 
kepala sekolah membangun komunikasi yang sifatnya personal. Kepala MTS AL-Ikhwan Labungka sebagai leader mampu menampilkan pribadinya memiliki visi/misi serta mampu berkomunikasi dan mengambil keputusan.

\section{Tugas Kepala Sekolah Dalam}

\section{Melakukan Pengawasan}

Dalam tugas kepala sekolah melakukan pengawasan, hasil wawancara-wawancara di atas juga diperkuat dengan hasil observasi peneliti. ditemukan bahwa pengawasan yang dilakukan oleh kepala sekolah sudah sesuai dengan porsi beliau sebagai seorang pimpinan. Apabila guru ataupun siswa yang diawasi melakukan sesuatu yang benar maka akan mendapatkan reward, sedangkan yang tidak melakukan sesuatu yang secara benar maka akan mendapatkan teguran. Pengawasan tersebut meliputi pengawasan sikap, tingkah laku, perbuatan atau kegiatan yang dilakukan guru dan staf secara wajar. Aturan-aturan pengawasan sering disosialisaikan kepada guru, staf dan seluruh siswa agar dapat dilaksanakan sesuai standar. Kepala sekolah bertugas sebagai seorang pengawas dalam lingkungan sekolah. pengawasan sebagai alat memperbaiki kesalahan atau penyimpangan yang dilakukan. Pengawasan dilakukan terhadap bidang-bidang seperti kurikulum, kesiswaaan, kantor, kepegawaian, perlengkapan, keuangan, dan perpustakaan. Oleh karena itu kepala sekolah mengawasi pengelolaan pengajaran, pengelolaan kepegawaian, pengelolaan kesiswaan, pengelolaan sarana dan prasarana, pengelolaan keuangan, dan pengelolaan hubungan sekolah dan masyarakat.

\section{Tugas Kepala Sekolah dalam Memberikan Motivasi dan Membangun Suasana Kerja yang Kondusif}

Peranan Kepala sekolah dalam memberikan motivasi kepada guru, tenaga kependidikan dan administratir sangat penting sehingga mereka bersemangat dan bergairah dalam menjalankan tugasnya dalam rangka meningkatkan mutu pendidikan. Motivasi bisa diberikan dalam bentuk hadiah atau hukuman baik fisik maupun non-fisik. Dalam memberikan motivasi Kepala sekolah mempertimbangkan rasa keadilan dan kelayakan karena hal ini penting bagi Kepala sekolah untuk menciptakan iklim yang kondusif. Seorang pimpinan, kepala MTs Al-Ikhwan Labungka dituntunt untuk memiliki motivasi diri yang kuat dalam melaksanakan tugas dan fungsinya di satuan pendidikan yang 
dipimpinya. Hal ini akan mendorong kepala sekolah tampil sebagai pemimpin yang luar biasa. Pemimpin luar biasa mengerjakan tugas pokok dan fungsi melebihi dari apa yang seharusnya dilakukan menurut standar "minimal". Motivasi diri yang ada pada setiap kepala sekolah, juga menjadi sumber semangat yang mendorongnya untuk melakukan tindakan (motivasi eksternal) terhadap warga sekolah lainnya (guru, pegawai dan peserta didik) untuk secara bersama-sama mencapai tujuan yang telah ditetapkan.

Dengan demikian peningkatan profesionalisme guru tidak luput dari perhatian kepala sekolah seperti mengikutsertakan guru-guru dalam berbagai penataran dan pelatihan. Peran kepala sekolah sebagai pendidik dalam bingkai implementasi kepemimpinannya. Kepala sekolah juga memberi contoh dalam mendidik misalkan dengan mengajar 6 jam seminggu, sebelum mengajar kepala madrsah membuat program tahunan, program semester, syllabus, rencana pembelajaran, analisis, sistem evaluasi. Hal ini dilakukan untuk memberi tauladan kepada rekan kerja atau guru-guru yang lain.

Sifat-sifat kepala sekolah juga cukup dikagumi dengan keikhlasan dan kesabarannya oleh guru-guru MTs Swasta Al-Ikhwan Labungka, hidup yang sederhana menjadi kepribadiannya, bersikap tawakal dan pengabdian yang penuh dedikasi. Dalam menciptakan suasan kerja yang kondusif dan dapat menjadi panutan bagi komponen Sekolah. Peranan inovator ditunjukan dalam bentuk kemampuan membangun inovasi, mengadopsi atau memodifikasi gagasan baru yang berguna bagi kepentingan sekolah. Berkaitan perannya sebagai inovator, Kepala sekolah mampu mengatur lingkungan Sekolah dan menciptakan hubungan kerja yang harmonis dan kondusif. Hasil wawancara dengan pedoman model kedua berkaitan dengan pertanyaan seputar kewenangan kepala sekolah, mekanisme pembuatan keputusan, proses penetapan kebijakan, pola komunikasi, proses pengawasan, proses aktualisasi ide/saran, pemberian motivasi, kondisi kesetiaan, dan suasana kerja. Item-item tersebut disampaikan atau ditanyakan kepada ketua komite sekolah, pengawas, guru, dan pegawai Tata Usaha. Menurut ketua komite sekolah, dalam manjalankan tugas dan peranannya sebagai Kepala sekolah, ia senantiasa mengedepankan musyawarah dan konsultasi kepada komite sekolah. Pembuatan keputusan dan proses penetapan kebijakan juga 
dilakukan berdasarkan masukan dari semua elemen sekolah. Pola komunikasi yang dikembangkan pula bercorak terbuka dan berlangsung timbal balik sesuai dengan norma yang disepakati bersama.

Dengan demikian, guru dan kepala sekolah selalu bekerjasama dalam meningkatkan kualitas siswa dan sekolah. Selain itu juga, kepala sekolah perlu membenahi kekurangan-kekurangan apa yang ada di sekolah seperti pengadaan sarana dan prasarana, pelatihan guru untuk menyusun perubahan kurikulum pembelajaran lebih ditingkatkan lagi agar kualitas siswa dan sekolah bisa bersaing dengan sekolah lain.

\section{KESIMPULAN}

Indikator yang menunjukkan perilaku kepala sekolah terkait dengan gaya kepemimpinannya tersebut terlihat pada hal-hal sebagai berikut; Kepala sekolah mendorong dan meningkatakan kesadaran tentang betapa pentingnya dan bernilainya sasaran yang akan dicapai kelak dan menunjukkan cara untuk mencapainya. Mendorong guru staf dan lainnya untuk mendahulukan kepentingan kelompok daripada kepentingan pribadi. Meningkatkan kebutuhan guru staf dan lainnya yang lebih tinggi seperti harga diri dan aktualisasi diri. Dalam berbagai hal membangun komitmen bersama terhadap sasaran organisasi dam memberikan kewenangan berupa kepercayaan kepada para pengikutnya yaitu guru, staf dan karyawan untuk mencapai sasaran. Jalannya organisasi bukan digerakan oleh birokrasi tetapi oleh kesadaran bersama hal ini sejalan dengan MBS dimana kewenangan sekolah dalam pengelolaan sangat luas, juga adanya partisipasi aktif dari stakeholder.

Ada tiga saran yang dapat peneliti sampaikan pada penelitian ini sebagai kontribusi atau sumbang pemikiran terhadap gaya kepemimpinan kepala sekolah yang demokratis di mts swasta al-ikhwan labunga kabupaten muna; Diharapakan kepala sekolah MTs Swasta Al-lhkwan Labungka dapat menggunakan hasil penelitian ini sebagai pedoman untuk terus konsisten memperbaiki dan mengembangkan lembaga/sekolah yang dipimpinnya. Sebaiknya prestasi yang sudah dicapai sekarang ini dapat ditingkatkan agar kepala sekolah dapat memberikan kontribusi yang positif bagi kemajuan sekolah-sekolah dan lingkungan di sekitarnya. Untuk peneliti berikutnya, diharapakn dapat menjadikan hasil penelitian ini sebagai salah satu pedoman atau acuan dalam mengadakan penelitian dengan variabel yang berbeda.

\section{DAFTAR PUSTAKA}

Anoraga, P. 2002. Psikologi kepemimpinan. Jakarta: Rineka Cipta. 
Bass \& Yukl. 1989. Human Motivation. New York: Cambridge University

Buchari, Zainun. 1989. Manajemen dan Motivasi. Jakarta: Balai Aksara

Buchari, Zainun. 1989. Manajemen dan Motivasi. Jakarta: Balai Aksara

Davis \& Newstrom. 2005. Managing Human Resource Productivity, Quality of Work, Life and Profit, 4th. Edition. New York : Mc.Graw Hill, Inc.

Depdiknas. 2000. Manajemen Peningkatan Mutu Berbasis Sekolah. Jakarta: Gunung Agung.

Greenfield. 2007. Organisasi dan Manajemen: Perilaku, struktur, proses. (Diterjemahkan oleh Nunuk Adiarni MM, Editor: Lydon Saputra). Jakarta: PT. Bina Aksara.

Handoko, T, Hani. 2001. "Manajemen". Yogyakarta: BPFE.

Handoko, T, Hani. 2001. "Manajemen". Yogyakarta: BPFE.

Heck, dkk. 2001. Antropologi Pendidikan. (Diterjemahkan oleh Imran Manan). Jakarta: P2LPTK, Ditjen Dikti, Depdikbud.

Heck, dkk. 2001. Antropologi Pendidikan. (Diterjemahkan oleh Imran Manan). Jakarta: P2LPTK, Ditjen Dikti, Depdikbud.

Huberman dan Miles B, A.M,. 2007. Qualitative Data Analysis: A
Sourcebook of New Methods. Sage Publications: London.

Kartono, Kartini. 2008. Pemimpin dan Kepemimpinan. Jakarta: CV. Rajawali.

Komariah. 2011. Metodologi Pendekatan Kualitatif (Edisi Revisi). Bandung: PT Remaja Rosdakarya.

Nana, Syaodih. 2007. Metode Penelitian Administrasi. Bandung: Alfabeta.

Samino, A. 2012. Profesionalisme Keguruan. Yokyakarta: Kanisius.

Samino. 2012. Kepemimpinan Pendidikan. Solo: Fairuz Media

Saprin. 2010. Optimalisasi Fungsi Manajemen Dalam Pembelajaran: Tesis. Makassar: Fakultas Tarbiyah dan Keguruan UIN Alauddin Makassar Press.

Siagian, S.P. 2003. Teori dan Praktek Pengambilan Keputusan. Jakarta: CV Haji Masagung.

Siagian, S.P. 2003. Teori dan Praktek Pengambilan Keputusan. Jakarta: CV Haji Masagung.

Sugiyono. 2011 Metode Penelitian Kombinasi (mixed methods) Bandung: CV. Alfabeta

Sutrisno. 2010. Kepemimpinan Pendidikan. Yogyakarta. PT Pustaka Insan Madani.

Tanjung, Rahman Arif. 2006. Kepemimpinan Kepala Sekolah Dalam Penerapan Manajemen Berbasis Sekolah pada SMA Negeri I Gunung Sindur Bogor. Jakarta: P2LPTK, Ditjen Dikti, Depdikbud. 
Thoha, Miftah. 2003. Kepemimpinan Dalam Manajemen. Jakarta : PT. Raja Persada.

Tichy \& Devanna. 1986. Multi Auditor Judgment/Decision Making Research: A Decade Later: Journal of Accounting Literature. Vol. 16: 86-126.

Wagiman, H.A. 2005. Persepsi Guru Terhadap Gaya Kepemimpinan Kepala Sekolah SD Tarakanita Jakarta. Jakarta: Kanisius

Wahjosumidjo. 2001. Kepemimpinan dan Motivasi. Jakarta: Ghalia Indonesia. 